Article

\title{
Globalization and Modern Slavery
}

\author{
Todd Landman * and Bernard W. Silverman \\ School of Politics and International Relations, University of Nottingham, Nottingham, NG7 2RD, UK; \\ E-Mails: todd.landman@nottingham.ac.uk (T.L.), mail@bernardsilverman.co.uk (B.W.S.) \\ * Corresponding author
}

Submitted: 14 May 2019 | Accepted: 25 July 2019 | Published: 25 November 2019

\begin{abstract}
This article presents a cross-national comparative analysis of the relationship between different dimensions of globalization and modern slavery. It argues that both the economic and political dimensions of globalization are strongly associated with lower levels of slavery prevalence. Recent estimates suggest there are more than 40 million people in some form of slavery and the United Nations has committed the world to ending this problem by 2030. Some argue that a race to the bottom, and the structure of economic incentives associated with globalization have contributed to the problem of modern slavery. Others argue that increased openness and the diffusion of values, the spread of democratic forms of rule, and the advance of human rights that come with globalization limit modern slavery. This article presents a preliminary empirical analysis of these arguments using data on slavery prevalence across more than 60 countries and various measures of economic and political globalization. The analysis shows that economic measures of globalization and higher levels of democracy are significantly related to lower levels of slavery prevalence, even after controlling for armed conflict and regional differentiation. In order to support these findings, the article examines the international law on slavery, definitions and conceptions of modern slavery, and comparative data on slavery prevalence modeled across indicators of economic and political globalization. It concludes with a discussion of the implications of these findings for the trade-offs between globalization and modern slavery.
\end{abstract}

\section{Keywords}

armed conflict; economic development; forced labour; globalization; human rights; modern slavery; worker rights protection

Issue

This article is part of the issue "Trade-Offs in the Political Realm: How Important Are Trade-Offs in Politics?" edited by Todd Landman (University of Nottingham, UK) and Hans-Joachim Lauth (University of Wuerzburg, Germany).

(C) 2019 by the authors; licensee Cogitatio (Lisbon, Portugal). This article is licensed under a Creative Commons Attribution 4.0 International License (CC BY).

\section{Introduction}

Globalization is a contested economic, social, and political phenomenon whose key features include the breaking down of traditional territorial borders, the redefinition of regions, new divisions of labour and the distribution of power, and a changing role of culture (Hermann, 2010). Its contestation varies across different sets of dimensions. First, there is a question as to whether it is progressive, linear, and/or inevitable (see, e.g., LeBaron, 2016). Second, there are concerns over whether it is a mere description of what is happening in the world or offers a deeper causal theory of economic, social, and political change (Landman \& Carvalho, 2016; Li \& Reuveny, 2003). Third, there are arguments that it has been 'oversold' as to its overall positive benefits and importance (Held \& McGrew, 2007; Held, McGrew, Goldblatt, \& Perraton, 1999; Stiglitz, 2005, p. 229, 2017). The post $9 / 11$ world has certainly brought new challenges to the idea of globalization as a positive and enlightening force for change. Some argue that there is evidence of a backlash against globalization and globalist aspirations. This evidence includes the growth in nationalist movements, some interpretations of the 2016 vote 
of the UK to leave the European Union, the electoral victories of decidedly nationalist politicians in the US and Brazil, and the growing strength of right wing political parties in France, the Netherlands, and Italy (see Norris \& Inglehart, 2019). Various indicators of globalization show increased inter-connectedness, economic flows of trade and investment, high levels of popular support for different dimensions of globalization (World Economic Forum, 2018), and until very recently (Diamond \& Plattner, 2015; Diamond, Plattner, \& Walker, 2016), the growth of democracy and human rights (Held \& McGrew, 2007, p. 1; Landman, 2013). Patterns of cultural and political diffusion have seen the third and fourth waves of democratization (Deutsch \& Welzel, 2016; Doorenspleet, 2005; Huntington, 1991; Inglehart, 1997; Inglehart \& Welzel, 2005; Landman, 2013; Whitehead, 1996), the proliferation of human rights instruments and improved human rights enjoyment (Fariss, 2014; Landman, 2005b; Simmons, 2009; Welzel, 2013), an 'economic geography of human rights' (Edwards, Kernohan, Landman, \& Nessa, 2018), as well as a 'justice cascade' (Risse, Ropp, \& Sikkink, 1999, 2013; Sikkink, 2011).

Alongside these debates around the true nature and extent of globalization and its demonstrable impact has been renewed attention to the phenomenon of modern slavery. Popular awareness of the problem varies, but there has been an increase in the formal political recognition of the problem at international and national levels. United Nations Sustainable Development Goal (SDG) 8.7 (United Nations Development Programme, 2015) calls for member states to '[t]ake immediate and effective measures to eradicate forced labour, end modern slavery and human trafficking and secure the prohibition and elimination of the worst forms of child labour.' National governments, like the UK and Australia, are passing laws to combat modern slavery and to hold large organisations to account for the degree to which their operations are affected by the problem. International and national non-governmental organisations (NGOs) work to raise awareness, advocate for change, make direct interventions, and provide support for slavery survivors.

Estimates of the prevalence of slavery have varied over the past few years, beginning with a series of calculations carried out by the Walk Free Foundation, which estimates that in 2013 there were 29 million slaves, followed by 36 million in 2014, and 45.8 million in 2016 . Alongside these figures for slavery, the International Labour Organisation (ILO) estimated that those in conditions of forced labour totaled 21 million, while in 2018, the ILO and Walk Free jointly estimated the number of slaves to be 40.3 million, a figure that includes forced marriage and forced labour. This suggests that as an absolute number there are more slaves alive today than at earlier points in human history, but as a relative number, a lower proportion of the global population enslaved than during earlier periods of legalised slavery. Like other human rights problems, the phenomenon of modern slavery suffers from the fundamental problem of un- observability and intractability. Human rights measurement efforts have included 'standards-based' measures (see Landman \& Carvalho, 2009) for worker rights, including the scale developed by the Cingranelli and Richards 'Human Rights Data Project' (Cingranelli, Richards, \& Clay, 2014). Given that slavery prevalence is susceptible to different socio-economic, political, and cultural drivers, it is possible to test the degree to which different attributes of economic and political globalization are related to slavery prevalence.

The key question for this article is whether there is a trade-off between globalization and slavery. Increasingly systematic efforts to measure and estimate the problem of slavery show that it is indeed widespread and not isolated to developing countries alone, while some have argued that the development of global capitalism and processes of globalisation are in part to blame for the phenomenon (LeBaron, 2016, p. 382). Is it possible to have increased patterns of globalization without the downside of precarious labour conditions, some of which include modern slavery? Is slavery the 'dark underbelly of globalisation' (O'Connell Davidson, 2014, p. 29) or do the benefits of globalisation in terms of opening up economic and political contexts to trade, technology, values, and models of governance actually reduce the prevalence of slavery? Any attempt to begin to answer such questions requires a systematic analysis of the variation in the prevalence of slavery to see the degree to which such variation is related to the economic and political dimensions of globalization.

Using the 2016 and 2018 country level estimates of slavery prevalence provided by the ILO and Walk Free Foundation, this article provides the first systematic cross-national analysis of the relationships between different dimensions of globalization and modern slavery. Walk Free's methodology in partnership with the Gallup Organisation and the ILO uses survey methods to obtain country level prevalence estimates in a number of countries, and then extrapolates these to those countries for which there were no surveys. The extrapolation method is contested for a number of reasons (Silverman, 2018), and in any case does not lead to independent estimates for the various countries. For these reasons, we use the prevalence data for only those countries in which household surveys were administered. The total number of observations across the two years are thus 70. As a cross check on these prevalence data, we also use the worker protection scale developed by Cingranelli and Richards coded from the US State Department annual country reports. The coding for this variable includes: (1) the right of association; (2) the right to organize and bargain collectively; (3) a prohibition on the use of any form of forced or compulsive labour; (4) a minimum age for the employment of children; and (5) acceptable conditions of work with respect to minimum wages, hours of work, occupational health and safety (Cingranelli et al., 2014, p. 65). These data have been used, for example, in studies on structural adjustment, trade, and direct foreign in- 
vestment (see Abouharb \& Cingranelli, 2007; Neumayer $\&$ de Soysa, 2007) and range from 0 (no worker rights protection) to 2 (full worker rights protection).

The quantitative modelling includes independent variables that capture the economic and political dimensions of globalization that have appeared in the extant literature on globalisation, trade, foreign direct investment (FDI), democratization, and the diffusion of human rights. The results of our bivariate analysis show that slavery prevalence is significantly lower in countries with: (1) high levels of economic development (per capita GDP); (2) high levels of globalisation (using the KOF Globalisation Index); (3) high levels of democracy; (4) better records of protecting so-called 'physical integrity rights' (see Landman, 2005b; Landman \& Larizza, 2009; Poe \& Tate, 1994; Poe, Tate, \& Keith, 1999); and (5) countries that are not involved in some form of armed conflict. The multivariate analysis shows that across a variety of different model specifications, there are statistically significant relationships between economic development, globalisation, and democracy on the one hand, and lower levels of slavery prevalence on the other hand, even after controlling for the presence of armed conflict and regional differentiation. While this level of aggregate cross-country analysis cannot, at present, be broken down into different economic sectors, nor unpack more complicated country level processes, it does suggest that globalisation itself may not be the root cause of the problem.

To develop the argument and carry out this analysis, the article has five sections. Section 2 provides a definition of modern slavery that scholars and activists have used to underpin prevalence estimations. Section 3 presents a number of stylised facts and descriptive statistics for the measure of prevalence using the estimates from the 2016 and 2018 Global Slavery Index (GSI) reports. Section 4 discusses the data and methods used for the analysis. Finally, Section 5 summarizes the results and discusses the implications for understanding the trade-offs between globalization and modern slavery.

\section{Definitions of Slavery}

Popular understandings of slavery often conjure up images of African slaves brought to the Caribbean, Brazil, and the US, where such images typically include slave ships, slaves bound in chains, and slaves auctioned at market. Such imagery tends to obscure current realities of slavery and relegate it as a problem of the past. Scholars of modern slavery (e.g., Bales, 1999, 2005, 2007; Bales \& Soodalter, 2009; Bales, Trodd, \& Williamson, 2009; Choi-Fitzpatrick, 2017), however, argue that slavery is alive and well and that it has taken on new forms or updated old forms comprising a variety of practices that include (but are not exclusive to) debt bondage, domestic servitude, forced prostitution, forced labour, forced marriage, and human trafficking (Choi-Fitzpatrick, 2017, p. 11; Cockayne, Grono, \& Panaccione, 2016; Office of the High Commissioner for Human Rights, 2002). These same scholars also argue that slavery is not a 'third world' problem or problem of the 'global south,' but rather one that is truly global in reach.

As in much human rights work, international law and norms are an excellent starting point for defining slavery. Article 1(1) of the 1926 Slavery Convention (League of Nations, 1926) defines slavery as the status or condition of a person over whom any or all of the powers attaching to the right of ownership are exercised, 'where the ideas of ownership and property are given primacy. Additional legal developments have further articulated the definition of slavery, such as the 1956 Supplementary Convention on the Abolition of Slavery, the Slave Trade, and Institutions and Practices Similar to Slavery (Article 7a), the 1998 Rome Statute (Article 7.2.c), which established the International Criminal Court, the International Tribunal for the Former Yugoslavia (Article 5c), the 2000 United Nations Palermo Protocol on Trafficking in Persons and the 2005 Council of Europe Convention on Action against Trafficking in Human Beings.

The Bellagio-Harvard Guidelines on the Legal Parameters of Slavery, from 2012, bring these various legal strands together, both in terms of the right to ownership, the powers attached to the right of ownership, and the notion of possession. In focussing on these elements as foundational to slavery, the guidelines emphasise the notion of control and lack of agency for victims of slavery, where different forms of coercion maintain power over individuals and prevent them from leaving the conditions of their enslavement. This denial of agency is crucial to the definition of modern slavery and moves it away from a strict focus on 'property' and 'ownership' to one of relative power relations, coercion, and inability for slaves to leave their conditions of enslavement (Choi-Fitzpatrick, 2017; Cockayne et al., 2016; Landman, 2018). While ownership and selling of individuals still takes place (e.g., the slaves traded in Northern Libya in 2017), other forms of activity associated with ownership include transfer of persons, using people, managing the use of a person, profiting from the use of a person, transferring a person to an heir or successor, and/or the disposal, mistreatment or neglect or destruction of a person.

In the context of the UK, for example, the Home Office has specified a typology of slavery with 17 different categories across different forms of labour exploitation, domestic servitude, sexual exploitation, and criminal exploitation (Cooper, Hesketh, Ellis, \& Fair, 2017). In addition to this typology, the Home Office used a Multiple Systems Estimation (MSE) approach, based on data from various sources collated by the National Crime Agency, to yield an estimate of 10,000 to 13,000 UK victims (Bales, Hesketh, \& Silverman, 2015). Similar analysis has been done for the Netherlands and the city of New Orleans (Bales, Murphy, \& Silverman, in press; Silverman, in press; van Dijk, van der Heijden, \& Kragten-Heerdink, 
2016). The Walk Free estimates across Europe vary from less than 30 in Iceland to over 500,000 in the Russian Federation. The individuals that comprise these figures are typically found working in construction, agriculture, domestic service, in nail bars, hair dressers, drug houses, farms, car washes, adult parlours, and even as street performers in popular tourist destinations, where the day's takings are confiscated by gang masters and controllers. In each of these cases, the enslaver has some form of control or coercion that maintains the condition of enslavement, while the categories of slaves vary considerably across a wide range of economic sectors and markets. The nature of the enslavement means that slaves are often hidden in plain sight, and that investigators, the police, bank staff, health professionals, and even passers-by can assist in the identification of slaves in order for law enforcement to provide assistance and in some cases, pursue criminal prosecution. The BellagioHarvard Guidelines have therefore been a useful tool for setting the parameters and conditions for identifying modern slavery. Walk Free has adopted the BellagioHarvard Guidelines as its working definition of slavery, underpinning the GSI estimates.

\section{Stylised Facts and Descriptive Statistics}

In the absence of cross-national MSE-derived prevalence data, we opt to use the country level estimates from the GSI. The two versions of the GSI from 2016 and 2018 provide data on a range of variables relating to modern slavery, including measures of vulnerability, prevalence, and government response. This article is concerned with explaining the cross-national variation in the prevalence of slavery as its primary focus. The prevalence measure is expressed as the estimated proportion of the total population in modern slavery (\%), which are produced from mapping the vulnerability of individuals revealed through the use of Gallup administered household surveys. The estimation comes from the positive responses to a series of questions relating to the forced nature of work, the inability to leave, the duration of the condition, and/or the condition of forced marriage (ILO \& Walk Free Foundation, 2017). These questions are in line with the content of the Bellagio-Harvard Guidelines for the Legal Parameters of Slavery discussed above. For forced labour, the questions focus on the immediate family network, the presence of forced labour experience by anyone in the immediate family, who this person is (including their age and sex), when and for how long the condition lasted, the country in which it took place, the type of work that the person was forced to do, and the means of coercion that was used (ILO \& Walk Free Foundation, 2017 , p. 52). The fact that the surveys are administered to a random sample of households allows the estimation to be made as to the prevalence of forced labour and forced marriage as a percentage of the whole population. We use the prevalence measure only for those countries where Gallup conducted a household survey on behalf of
Walk Free (Silverman, 2018; Walk Free Foundation, 2016; Walk Free Foundation \& ILO, 2018). Observational independence is a crucial assumption of statistical analysis so we chose data based on actual household surveys carried out. Walk Free used surveys from 25 countries in 2016 and 45 countries in 2018. Our data set thus has 70 total observations and provides enough degrees of freedom (DF) for the analysis we conduct here. There were 22 countries where surveys were carried out for both the 2016 and the 2018 exercises. Because these surveys were independent, each such country is included twice in the data set.

The GSI tends to focus on a global map of prevalence and single-country case studies and discussion; however, it is equally important to examine the overall distribution of prevalence for the observations in our sample to provide additional insights into the nature and extent of modern slavery. Figure 1 shows a histogram of slavery prevalence for those countries where Walk Free and Gallup administered a household survey, putting together the 2016 and 2018 samples. The histogram is constructed on a logarithmic scale and it can be seen that the logarithms of prevalence follow a relatively normal distribution. The median value of prevalence is $0.46 \%$, the lower and upper quartiles $0.26 \%$ and $0.77 \%$, and the extreme values $0.08 \%$ and $2.22 \%$. In addition to this estimation of prevalence, the Cingranelli and Richards Human Rights Data Project has coded worker rights protection from a close reading of US State Department annual country reports. The scale ranges from 0 (no worker rights protection) to 2 (strong worker rights protection), where it is clear that the most countries are grouped around 0 and 1 with a small number of countries receiving a score of 2 . Figure 2 shows a histogram for the CIRI worker rights protection measures, where the limited nature of the variable shows strong country clustering for the 0 and 1 scores. There is a weak correlation between these two measures $(r=-0.20 ; p<0.10)$, where the mean prevalence level for each value of the scale are as follows: 0.66 for countries coded $0,0.58$ for those coded 1 , and 0.35 for those coded 2 . The GSI estimate is a more direct measure of prevalence than the CIRI variable, which includes forced labour alongside other dimensions of worker rights protection. We thus specify the estimated prevalence of slavery as our dependent variable.

\section{Modelling Globalization and Slavery}

This article tests the relationship between different indicators of globalization and slavery prevalence. There are indeed micro foundations for slavery, which are based on (1) instrumental rationality, market conditions and the structure of incentives; (2) criminality and deviance; (3) cultural framings and inter-subjective understandings (Choi-Fitzpatrick, 2017) and household and community relations (International Organisation for Migration [IOM], 2018). The level of analysis presented here, however, focuses on aggregate measures of slavery and how they re- 


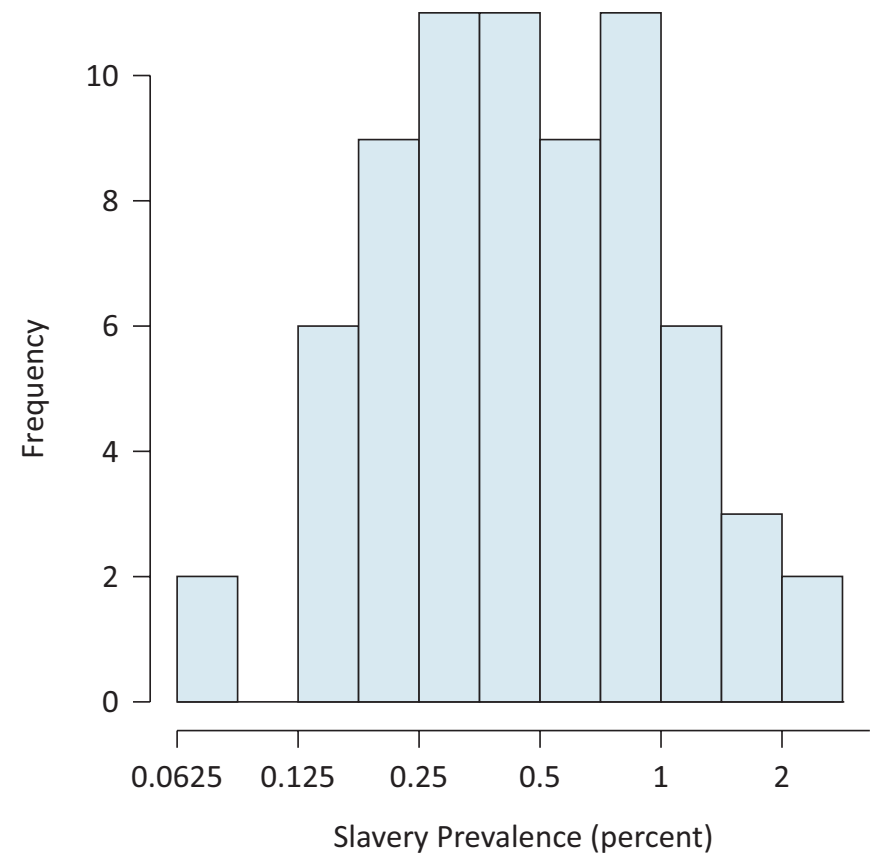

Figure 1. Histogram of estimated prevalence of slavery (after GSI). The histogram is constructed and presented on a logarithmic scale.

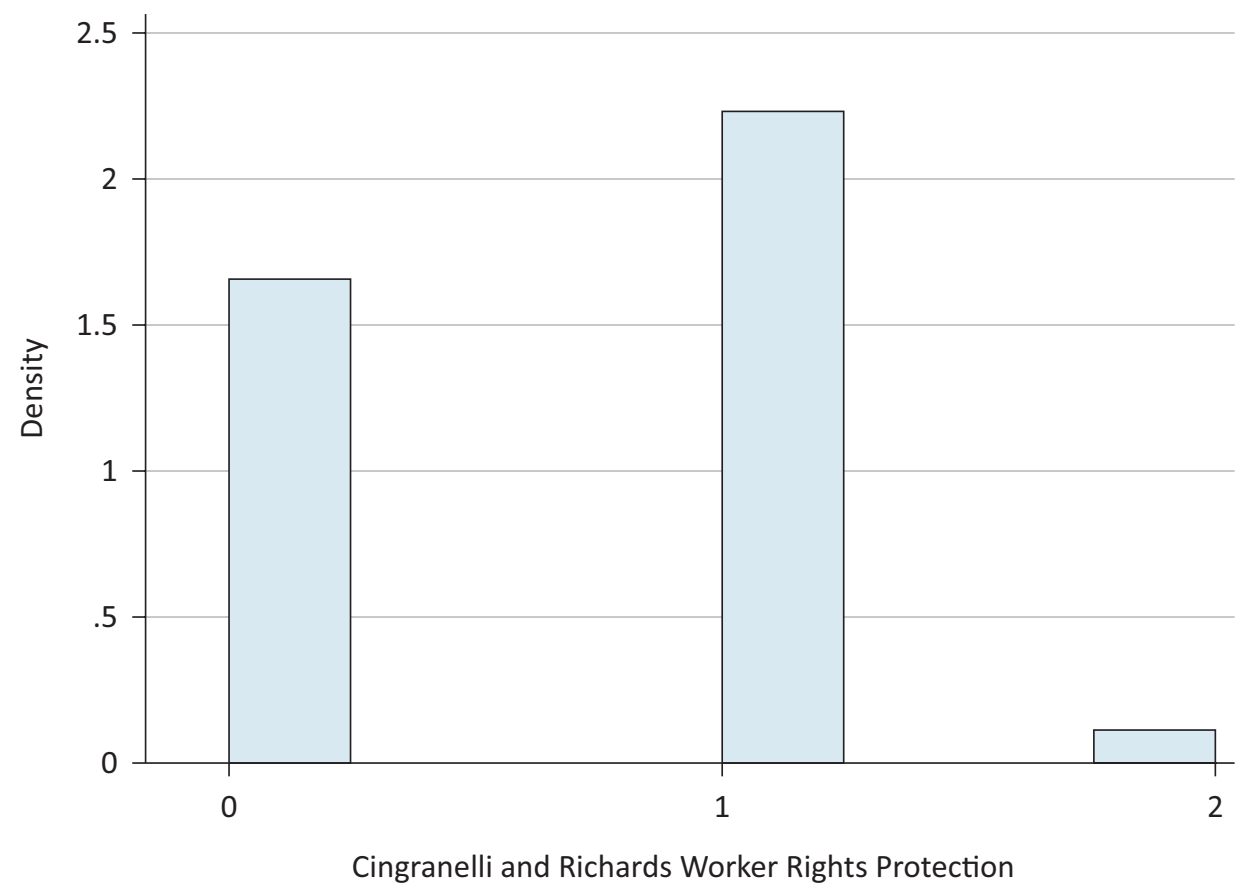

Figure 2. Histogram of worker rights protection.

late to different dimensions of globalization. There have been earlier and related attempts to examine the relationship between globalization and forced labour. For example, Manzo (2005a, 2005b) examined the processes of uneven development and trafficking, slavery among children, and 'deproletarianisation' in West Africa, with a particular focus on media reports in Côte d'Ivoire. LeBaron and Ayers (2013) examine the relationship between neo-liberalism (for many the dominant economic model of globalization) and modern slavery in Africa, where they link labour market reform and privatisation with the rise of 'unfree' labour. Jian and LaFree (2017) examine the relationship between trade openness and human trafficking, finding that countries making the transition between low and high levels of trade openness struggle to avoid increased levels of trafficking. Finally, and most related to the analysis presented here, Neumayer and de Soysa (2007) analyse the relationship between 
trade openness and FDI on the one hand with women's rights and the protection of labour rights on the other, using the CIRI worker rights protection scale as their main dependent variable. Across a cross-section of 166 countries, they find that trade openness is positively related to better protection of women's economic rights and worker rights, alongside additional variables such as overall levels of development and democracy.

Drawing on these earlier studies and the work on globalization more generally, we derive a number of observable implications that we examine empirically. On the positive side, it is argued that there are a number of plausible tangible benefits to globalization that stem from countries opening up their economic and political systems to the influences of trade, technology transfer, and the diffusion of values. Participation in the economic dimensions of globalization can have a positive impact on economic development, which in turn can lead to value change and the embrace of systems of governance that adhere to democratic principles and the protection of human rights (Inglehart, 1997; Inglehart \& Welzel, 2005; Welzel, 2013). The work on the 'Kantian Peace' shows that increased trade, the advent of 'civic republican' systems of governance (read democracy and human rights), and increased participation in global governance regimes (however weak they might be) can significantly reduce the probability of 'militarised disputes' (Russett \& O'Neal, 2001), which in turn are related to the problem of modern slavery. Overseas development assistance and trade can also lead states to participate in the international regime for the promotion and protection of human rights (Landman, 2005a; Simmons, 2009; Smith-Cannoy, 2012). On this view, globalization ought to be good for combatting slavery and should be related to lower levels of slavery prevalence.

On the negative side, it is argued that the process of globalization is uneven, creates inequalities, and varies in its impact across different economic sectors and across the quality of democracy and the protection of human rights (O'Connell Davidson, 2014; LeBaron, 2016). For these arguments, economic globalization through increased trade and economic flows leads to the concentration of wealth within and between countries in ways that have differential impact on labour, marginalised peoples, and local communities. Capital-intensive extractive industries, labour-intensive manufacturing, textiles, fishing and other industries that comprise the contours of economic globalization bring with them structural inequalities, the proliferation of and complexity in supply chains, potential opportunities for labour exploitation, and the kinds of economic precarity and vulnerability that can lead to individuals falling into modern slavery. In addition, the growth of democracy and human rights protection can show great variation within and between countries, where varying degrees of state capacity and the quality of political institutions do not deliver on their promise, with pockets of dysfunctional deliberation, the persistence of informal and formal patron-client networks, and long term impunity and lack of accountability for human rights violations (see, e.g., Foweraker \& Treviso, 2016; Landman, 2013).

These contending views on the effects of globalisation remain theoretically ambiguous, and thus as a first step, it is helpful to engage in the kind of empirical analysis presented here. The availability of the GSI allows for a new analysis of these relationships with a different form of data (prevalence) on a more direct understanding of the most extreme form of exploitation. The concept that underpins the derivation of the prevalence measure is rooted in international human rights law and the Bellagio-Harvard Guidelines on the Legal Parameters of Slavery. This study thus adopts the research design approach used in Neumayer and de Soysa (2007) and Jian and LaFree (2017), namely, a cross-sectional analysis of globalization and modern slavery across a reasonably large selection of countries $(n=70)$. This kind of research design has been popular in studies of other human rights problems (see Mitchell \& McCormick, 1988), where data sets progressed from single time cross-section analysis to the use of pooled cross-section time series structures (see Landman \& Larizza, 2009; Poe \& Tate, 1994; Poe et al., 1999). There are not the data available to achieve this latter form of data structure, but our global sample of countries provides enough preliminary DF for useful analysis to illustrate the potential trade-offs associated with globalization and the problem of modern slavery.

The starting point for this macro-model is to understand that the phenomenon of modern slavery at first blush appears to be a wholly economic phenomenon; however, the anti-slavery and anti-trafficking movement argues that there are larger social, political, and cultural dimensions and 'determinants of vulnerability' that make individuals more likely to fall into slavery. The IOM argues that in addition to the individual determinants of vulnerability, there are family, community, and larger structural factors that when combined raise the probability that any one individual will fall into slavery or be trafficked (IOM, 2018, pp. 5-8). At the micro level, there are a series of socio-economic factors that can increase the probability of any individual to be trafficked or fall into slavery, while at the structural level, factors include poor governance, absence of accountability mechanisms, and weak rule of law, as well as long term stable economic factors (IOM, 2018, p. 7). This combination of economic and political factors is at the heart of the analysis presented in this article, which aligns with studies that seek to explain the variation in other human rights issues (see, e.g., Edwards et al., 2018; Mitchell \& McCormick, 1988; Poe \& Tate, 1994; Poe et al., 1999).

Across these previous studies, variables such as per capita GDP and income and land inequality are standard economic measures (see Landman \& Larizza, 2009), while those interested in the economic interaction between countries include variables such as FDI (see Janz, 2018). For its focus on the economic dimensions of globalization, the article uses several different variables. First, 
it uses World Bank data on per capita GDP as a measure of the level of overall economic development. Second, it uses the full KOF Globalisation Index (de facto and de jure) as a composite measure of globalisation (see Gygli, Haelg, Potrafke, \& Sturm, 2019; Potrafke, 2015). Third, it uses FDI as a percentage of total annual GDP for the period 2006-2017. The reason for calculating the ratio of FDI and GDP over this longer period is that the annual figures for FDI are extremely volatile. Fourth, it uses 'trade openness', which is expressed as the total value of import and exports as the percentage of annual GDP (see Jiang \& LaFree, 2017; Neumayer \& de Soysa, 2007; Squalli \& Wilson, 2011), and is one component of the KOF Globalisation Index. The bivariate analysis reported below shows that these variables are highly correlated with one another and feature across different model specifications estimated through multivariate analysis. For the political elements of globalization, the article uses three different measures, one for democracy and two for human rights. First, it uses the 'Liberal Democracy' measure for 2016 drawn from the Varieties of Democracy Project (see Coppedge, Lindberg, \& Skaaning, 2015). The scale ranges from 0 (low democracy) to 1 (high democracy). Second, it uses two different measures that are part of the Political Terror Scale. Both of them rate country human rights performance with respect to personal integrity rights (i.e., state violation of arbitrary detention, disappearance, torture, and extra-judicial killing) and are based on the Amnesty International annual reports (PTSAI) and the US State Department annual reports (PTSSD). The scales range from 1 (low violation of human rights) to 5 (high violation of human rights; see Poe \& Tate, 1994).

In addition to economic and political globalization, there are two further factors to take into account: armed conflict and regional differentiation. It is important to consider these two factors as controls, which may account for additional variation in the prevalence of modern slavery. Studies on modern slavery have linked its presence to armed conflict, where increased political instability, violence, and displacement and migration increase the chances that vulnerable populations will fall into some form of slavery, including child soldiers and human trafficking (Freedom Fund, 2016). Refugees and 'people on the move' can become unwittingly drawn into large criminal networks that move them from sites of conflict to safer havens and recipient countries with strong welfare systems to provide support. Once they have migrated, however, they can find themselves in modern forms of indentured servitude, where their passports are withheld and they engage in a variety of forms of economic activity from which they cannot escape. These patterns are complemented with child and female sexual exploitation and trafficking, as well as recruitment networks enslaving children to fight in armed conflict. The example of Libya in 2017 showed how the civil conflict between rival factions produced an open slave market in which young males are being sold. Armed conflict is coded as a simple dummy variable (i.e., 1 for armed conflict, 0 for no armed conflict) for all conflict types from the Uppsala Conflict Data Project (UCDP).

Finally, the geographical distribution of slavery is not uniform. Rather, it is highly skewed across countries such as India and Bangladesh in Asia; Mauritania and the Democratic Republic of the Congo in Africa; and Colombia in South America (GSI, 2016). There is undoubtedly some regional clustering in the prevalence of modern slavery, where, like other human rights problems cross-border diffusion underpins these observations (see Edwards et al., 2018). The model thus includes a series of regional dummy variable using World Bank categories for Asia, Sub-Saharan Africa, and Russia and Eurasia, which have the highest levels of slavery prevalence. Table 1 lists these variables, their description, and their sources.

As the data set for this article are for a cross-section of countries, estimation of the parameters of the model is a straightforward process using a series of ordinary least squares (OLS) regression models. The sample size of countries provides enough DF for the inclusion of the different independent variables. Table 2 shows the descriptive statistics for all the main variables in the model (excluding the regional dummy variables), including the total number of observations $(\mathrm{N})$, the minimum value,

Table 1. Variables and data used in the analysis of slavery prevalence.

\begin{tabular}{|c|c|c|}
\hline Variable Name & Description & Source \\
\hline EPSRAW & Estimated prevalence of Slavery 2016, 2018 & GSI 2016, 2018 \\
\hline CIRIRWRP & Worker Rights Protection & Cingranelli and Richards Human Rights Data \\
\hline KOFTOTAL & KOF Globalisation Index & Gygli et al. (2019) \\
\hline TRADE & Trade Openness & World Bank World Development Indicators (2018) \\
\hline FDI & FDI as a percentage of GDP, (mean 2007-16). & World Bank World Development Indicators (2018) \\
\hline PCGDP & Per capita GDP, 2016 & World Bank World Development Indicators (2018) \\
\hline VDEM2016 & Level of liberal democracy, 2016 & Varieties of Democracy \\
\hline PTSAI & Physical Integrity Rights & Political Terror Scale (Amnesty) \\
\hline PTSSD & Physical Integrity Rights & Political Terror Scale (US State Department) \\
\hline ARMEDCON & Armed Conflict (including internal) & Uppsala Conflict Data Project (UCDP) \\
\hline REGION & Regional categorical variable & World Bank World Development Indicators (2018) \\
\hline
\end{tabular}


Table 2. Descriptive statistics.

\begin{tabular}{|c|c|c|c|c|c|c|}
\hline Variable Name & Description & $\mathbf{N}$ & Min. & Max. & Mean & Median \\
\hline EPSRAW & Estimated prevalence of slavery, 2016, 2018 & 70 & $0.08 \%$ & $2.22 \%$ & $0.60 \%$ & $0.46 \%$ \\
\hline CIRIWRP & Worker Rights Protection & 70 & 0 & 2 & 61 & 1 \\
\hline KOFTOTAL & KOF Globalisation Index & 70 & 38.57 & 84.2 & 61.70 & 61.89 \\
\hline TRADE & Trade Openness & 70 & $21 \%$ & $310 \%$ & $77 \%$ & $64.9 \%$ \\
\hline FDI & FDI as a percentage of GDP (mean 2007-2016) ${ }^{1}$ & 70 & $0.34 \%$ & $20.14 \%$ & $4.54 \%$ & $2 . \%$ \\
\hline PCGDP & Per capita gross domestic product (GDP), $2016^{2}$ & 70 & 320 & 51880 & 5398 & 3580 \\
\hline VDEM2016 & Level of liberal democracy, 2016 & 70 & 0.11 & 0.78 & 0.40 & 0.45 \\
\hline PTSAI & Political Terror Scale (Amnesty) & 70 & 1 & 5 & 3.06 & \\
\hline PTSSD & Political Terror Scale (State Department) & 70 & 1 & 5 & 3.04 & \\
\hline ARMEDCON & All armed conflict & 70 & 0 & 1 & 0.34 & \\
\hline
\end{tabular}

Notes: ${ }^{1}$ The ratio is calculated over the period 2006-2017; ${ }^{2}$ The data are for 2016, but indexed to USD in 2010.

the maximum value, the mean, and the median. Medians are given for variables on continuous scales. For those variables with very skewed distributions, the logarithm of the variable gives a reasonably symmetric distribution, and is therefore used for the analysis.

\section{Findings}

This section of the article examines the second-order relationships between the prevalence of slavery and the other variables. Table 3 is a correlation matrix of all the variables with the exception of the regional variable. Reading down the first column shows that the prevalence of slavery is significantly correlated with worker rights protection, the overall level of globalisation, democracy, human rights, economic development, human rights and armed conflict. First, the correlation between slavery prevalence and worker rights protection is the weakest of the correlations. Second, higher levels of globalisation and economic development-PCGDPare associated with lower levels of slavery prevalence. Third, higher levels of democracy and greater protection of human rights are associated with lower levels of slavery prevalence. Third, the presence of armed conflict is associated with higher levels of slavery prevalence. The second column on worker rights protection shows that the correlations are very similar as those in the first column, but have a smaller magnitude and lower level of significance. Column three shows the strong correlations for all the main variables and globalisation. The strong correlation between the level of economic development ( $r=0.86, \mathrm{p}<0.001)$ is not surprising and will be taken into account in the multivariate analysis to address the problem of multicollinearity. Equally, the strong correlations for trade and FDI are not surprising since they are components of the KOF globalisation index.

As this article is primarily interested in the relationship between globalisation and slavery prevalence, Figure 3 is a scatterplot for the KOF Globalisation Index and the prevalence of slavery (logged). It is clear from the figure that those countries with a higher level of globalisation (e.g., Hungary, Poland, and Latvia) have a much lower level of slavery prevalence, while those with a much lower level of globalisation (e.g., Afghanistan, The Democratic Republic of the Congo, and Pakistan) have a much higher level of slavery prevalence. The notable outlier in the figure is Brazil, which has relatively lower level of globalisation and a lower level of slavery prevalence. Figure 4 shows this overall relationship as smoothed line with a $95 \%$ confidence interval, which captures its magnitude and significance. Both figures suggest that the relationship warrants further exploration that controls for other possibly confounding factors.

Moving beyond these bivariate relationships, we conducted a series of multivariate regression models for all the main variables, where slavery prevalence (logged) is

Table 3. Correlation matrix of all variables.

\begin{tabular}{|c|c|c|c|c|c|c|c|c|c|}
\hline & Ln(EPSRAW) & CIRIWRP & KOFTOTAL & Ln(TRADE) & $\operatorname{Ln}(\mathrm{FDI})$ & $\operatorname{Ln}(P C G D P)$ & VDEM2016 & PTSAI & PTSSD \\
\hline CIRIWRP & $-0.20 *$ & - & & & & & & & \\
\hline KOFTOTAL & $-0.59 * * *$ & $0.26^{* *}$ & - & & & & & & \\
\hline $\operatorname{Ln}(T R A D E)$ & -0.15 & 0.19 & $0.50 * * *$ & - & & & & & \\
\hline $\operatorname{Ln}(\mathrm{FDI})$ & -0.18 & 0.04 & $0.40 * * *$ & $0.62 * * *$ & - & & & & \\
\hline $\operatorname{Ln}($ PCGDP) & $-0.64 * * *$ & $0.26 * *$ & $0.86 * * *$ & $0.29 * *$ & $0.27^{* *}$ & - & & & \\
\hline VDEM2016 & $-0.56 * * *$ & $0.48 * * *$ & $0.49 * * *$ & 0.06 & -0.02 & $0.54 * * *$ & - & & \\
\hline PTSAI & $0.48 * * *$ & -0.18 & $-0.50 * * *$ & $-0.52 * * *$ & $-0.38 * * *$ & * $-0.42 * * *$ & $-0.49 * * *$ & - & \\
\hline PTSSD & $0.47^{* * *}$ & $-0.27^{* *}$ & $-0.63 * * *$ & $-0.57 * * *$ & $-0.42 * * *$ & * $-0.59 * * *$ & $-0.49 * * *$ & $0.78 * * *$ & * - \\
\hline ARMEDCON & $0.45^{* * *}$ & $-0.32 * *$ & $-0.38 * * *$ & $-0.51 * * *$ & $-0.30 * * *$ & $-0.34 * * *$ & $-0.51 * * *$ & $0.74 * * *$ & $* 0.73 * * *$ \\
\hline
\end{tabular}

Notes: Pearson's $r$. Significance levels are denoted: ${ }^{*} p<0.10 ;{ }^{* *} p<0.05 ;{ }^{* * *} p<0.001$. 


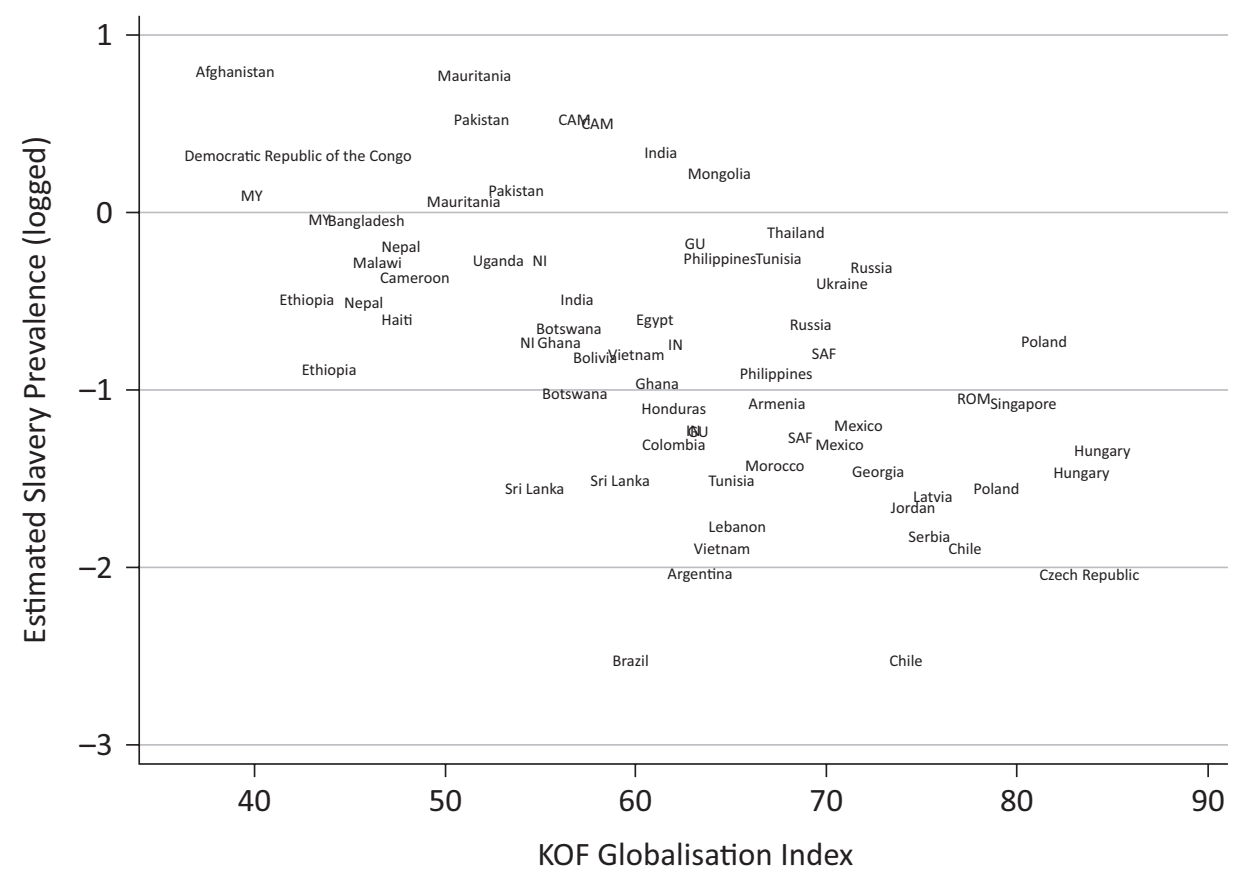

Figure 3. KOF Globalisation Index and slavery prevalence (logged). Note: For maximum ease of visualisation, abbreviated country names are as follows: Cambodia (CAM), Guatemala (GU), Indonesia (IN), Myanmar (MY), Nigeria (NI), Romania (ROM), and South Africa (SAF).

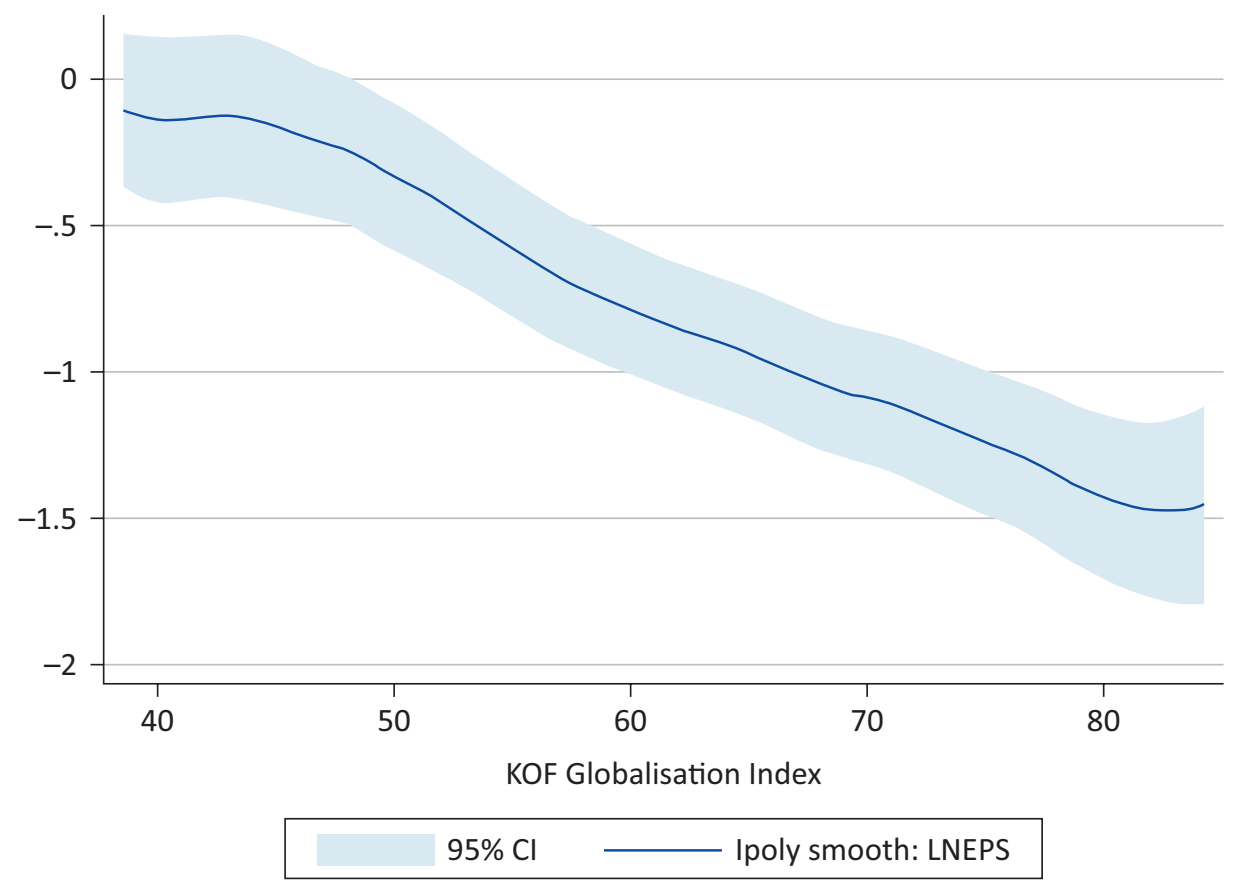

Figure 4. KOF Globalisation Index and slavery prevalence (logged): polynomial smoothed line with $95 \%$ confidence interval.

the dependent variable in order to understand the relative magnitude and significance of the relationships for our main independent variables of interest. Table 4 reports the results of our analysis for all the main variables. The table is broken into two main parts: one for models using democracy as an independent variable alongside the KOF Globalisation Index and the level of economic development, and the other for the two human rights scores as independent variables. Additional controls in- clude armed conflict and three regional dummy variables for those regions where slavery prevalence is the highest. Since armed conflict is significantly correlated with human rights, it is excluded from the human rights models. The different combination of variables yields 12 models overall.

Reading across the first row of the table shows that the KOF Globalisation Index is significantly related to lower levels of slavery prevalence for all the models in 
Table 4. Multivariate regression estimates for globalisation and slavery prevalence.

\begin{tabular}{|c|c|c|c|c|c|c|c|c|c|c|c|c|}
\hline \multirow[b]{2}{*}{ Ind. Variables } & \multicolumn{4}{|c|}{ Democracy Models } & \multicolumn{8}{|c|}{ Human Rights Models } \\
\hline & 1 & 2 & 3 & 4 & 5 & 6 & 7 & 8 & 9 & 10 & 11 & 12 \\
\hline KOFTOTAL & $\begin{array}{c}-0.03^{* * *} \\
(.006)\end{array}$ & $\begin{array}{r}-0.02 * * \\
(.008)\end{array}$ & & & $\begin{array}{c}-0.03^{* * *} \\
(0.007)\end{array}$ & $\begin{array}{c}-0.03^{* * *} \\
(0.008)\end{array}$ & $\begin{array}{c}-0.02 * * * \\
(0.008)\end{array}$ & $\begin{array}{c}-0.03^{* * *} \\
(0.009)\end{array}$ & & & & \\
\hline $\operatorname{Ln}($ PCGDP) & & & $\begin{array}{c}-0.35^{* * *} \\
(.07)\end{array}$ & $\begin{array}{c}-0.26 * * * \\
(.06)\end{array}$ & & & & & $\begin{array}{l}-0.39 * * * \\
(0.07)\end{array}$ & $\begin{array}{l}-0.42 * * * \\
(0.08)\end{array}$ & $\begin{array}{l}-0.32^{* * *} \\
(0.08)\end{array}$ & $\begin{array}{c}-0.35^{* * *} \\
(0.09)\end{array}$ \\
\hline VDEM & $\begin{array}{c}-1.19 * * \\
(.53)\end{array}$ & $\begin{array}{r}-1.05^{*} \\
(.55)\end{array}$ & $\begin{array}{c}-0.88^{*} \\
(.51)\end{array}$ & $\begin{array}{r}-0.75 \\
(.52)\end{array}$ & & & & & & & & \\
\hline PTSAI & & & & & $\begin{array}{c}0.18^{* *} \\
(0.08)\end{array}$ & & $\begin{array}{c}0.10 \\
(0.08)\end{array}$ & & $\begin{array}{c}0.18^{* *} \\
(0.07)\end{array}$ & & $\begin{array}{c}0.11 \\
(0.08)\end{array}$ & \\
\hline PTSSD & & & & & & $\begin{array}{c}0.12 \\
(0.09)\end{array}$ & & $\begin{array}{c}0.04 \\
(0.09)\end{array}$ & & $\begin{array}{c}-0.10 \\
(0.08)\end{array}$ & & $\begin{array}{c}0.03 \\
(0.08)\end{array}$ \\
\hline ARMEDCON & $\begin{array}{c}0.24 \\
(0.18)\end{array}$ & $\begin{array}{c}0.19 \\
(0.17)\end{array}$ & $\begin{array}{c}0.28 \\
(0.17)\end{array}$ & $\begin{array}{c}0.22 \\
(0.17)\end{array}$ & & & & & & & & \\
\hline \multicolumn{13}{|l|}{ Region } \\
\hline Asia & & $\begin{array}{c}0.54^{* *} \\
(0.21)\end{array}$ & & $\begin{array}{c}0.51^{* *} \\
(0.19)\end{array}$ & & & $\begin{array}{c}0.58 * * \\
(0.08)\end{array}$ & $\begin{array}{c}0.64^{* *} \\
(0.20)\end{array}$ & & & $\begin{array}{c}0.51^{* *} \\
(0.19)\end{array}$ & $\begin{array}{c}0.60 * * \\
(0.18)\end{array}$ \\
\hline Russia-Eurasia & & $\begin{array}{c}0.23 \\
(0.19) \\
\end{array}$ & & $\begin{array}{c}0.22 \\
(0.21)\end{array}$ & & & $\begin{array}{c}0.50^{*} \\
(0.30) \\
\end{array}$ & $\begin{array}{c}0.56^{*} \\
(0.31) \\
\end{array}$ & & & $\begin{array}{c}0.40 \\
(0.28) \\
\end{array}$ & $\begin{array}{c}0.48^{*} \\
(0.29) \\
\end{array}$ \\
\hline Sub-Sahara Africa & & $\begin{array}{c}0.42^{* *} \\
(0.19)\end{array}$ & & $\begin{array}{c}0.35^{* *} \\
(0.17)\end{array}$ & & & $\begin{array}{c}0.42 * \\
(0.23)\end{array}$ & $\begin{array}{c}0.43^{*} \\
(0.23)\end{array}$ & & & $\begin{array}{c}0.33 \\
(0.21)\end{array}$ & $\begin{array}{c}0.37^{* *} \\
(0.21)\end{array}$ \\
\hline Constant & $\begin{array}{l}1.22 * * * \\
(0.40)\end{array}$ & $\begin{array}{c}0.26 \\
(0.49)\end{array}$ & $\begin{array}{l}2.24^{* * * *} \\
(0.53)\end{array}$ & $\begin{array}{l}1.27^{* *} \\
(0.48)\end{array}$ & $\begin{array}{c}0.52 \\
(0.62)\end{array}$ & $\begin{array}{c}0.86 \\
(0.73)\end{array}$ & $\begin{array}{c}0.02 \\
(0.70)\end{array}$ & $\begin{array}{c}0.28 \\
(0.80)\end{array}$ & $\begin{array}{c}1.83^{* *} \\
(0.71)\end{array}$ & $\begin{array}{l}2.27^{* *} \\
(0.21)\end{array}$ & $\begin{array}{c}1.23 \\
(0.78)\end{array}$ & $\begin{array}{c}1.60^{*} \\
(0.90)\end{array}$ \\
\hline$\overline{\mathrm{R}^{2}}$ & 0.46 & 0.52 & 0.50 & 0.56 & 0.37 & 0.34 & 0.42 & 0.41 & 0.45 & 0.40 & 0.49 & 0.47 \\
\hline $\mathrm{N}$ & 70 & 70 & 70 & 70 & 70 & 70 & 70 & 70 & 70 & 70 & 70 & 70 \\
\hline
\end{tabular}

Notes: Dependent Variable: Natural log of estimated slavery prevalence. Unstandardised beta coefficients with robust standard errors in parentheses.

${ }^{*} p<0.10 ;{ }^{* *} p<0.05 ;{ }^{* *} p<0.001$. Method of estimation: OLS. 
which it is included, while the same is true for the level of economic development. This suggests that countries with a higher level of globalisation or economic development have lower levels of slavery prevalence. The results show that countries with higher levels of democracy also have lower levels of slavery prevalence. The inclusion of regional dummy variables shows that slavery prevalence is consistently higher in Asia relative to the rest of the world, with varying degrees of significance for Russia and Eurasia and Sub-Saharan Africa. Despite its significance in our bivariate modelling (see Table 3), armed conflict does not appear to have a significant relationship with slavery prevalence across any of the models. The $\mathrm{R}^{2}$ values for the models in the table show that these models explain between $34 \%$ and $56 \%$ of the variation in slavery prevalence.

\section{Summary and Implications}

Since it first gained global attention in the late 1990s, modern slavery has increased in salience as a public policy problem and as an intractable problem of development. This saliency has come from a growing recognition within government and as the result of advocacy from NGOs and anti-slavery activists. It is a persistent problem despite its legal abolition and a proliferation of anti-slavery laws, policies, and programmes. Our aim in this article has been to understand and explain the variation in slavery prevalence across a sample of countries with respect to different dimensions of globalization. We have been motivated by the question as to whether there is a dark side to globalization, which includes the emergence and maintenance of precarious labour conditions and modern slavery. We set out the contending arguments for the possible relationships between slavery prevalence on the one hand and the economic and political dimensions of globalization on the other. We used slavery prevalence data on those countries in which the Walk Free Foundation in partnership with Gallup developed a battery of questions in household surveys. Walk Free deployed these surveys to over 70,000 respondents that captured vulnerability to modern slavery. Their work grounds itself conceptually in the Bellagio-Harvard Guidelines on the Legal Parameters of Slavery. These estimates were then crosschecked against the Cingranelli and Richards scale for worker rights protection.

The descriptive analysis shows clearly that the distribution of slavery is highly variable across the countries in the sample. The bivariate relationships show that there are statistically significant correlations between prevalence of slavery and worker rights protection, the overall level of globalisation, economic development, and democracy. These findings were further borne out by our multivariate regression results, which show that globalisation, economic development, and democracy all have significant relationships with slavery prevalence, and that these models explain a decent range of varia- tion in slavery prevalence. One interpretation of these results is that is that globalised and/or richer countries have more resources, greater state capacity, and are more engaged with the global community in ways that mean that slavery prevalence is significantly lower. On our reading, it is thus too early to lay the blame for modern slavery at the feet of globalisation. As our sample of countries is quite conservative and only available for a limited amount of time means that draw this conclusion with some caution. Further research needs to unpack the dimensions of the empirical generalizations reported here. Breaking the data down by sector and for those industries that produce tradeable goods, for example, could possibly differentiate these relationships further. Tradeable goods are increasingly subject to international scrutiny that may limit the degree to which their production involves modern slavery, while domestic production of non-tradeable goods may well have higher levels of modern slavery and are not subject to such international scrutiny.

Our findings for democracy may relate in part to countries in the sample being part of the recent 'waves' of democratization, the pace and contours of which include elements of international diffusion and contagion (Edwards et al., 2018; Whitehead, 1996). For example, Chile is in our sample, a country that experienced prolonged authoritarian under the Pinochet regime between 1973 and 1988, when it made a transition to democracy. Brazil and Argentina are also transitional cases after period of authoritarian rule during the period from the mid-1960s to the mid-1980s. Mongolia and Mexico are also transitional countries (1991 and 2000, respectively). The sample also contains ex-communist countries such as the Poland and Hungary, which for the years of our sample have relatively high levels of democracy compared to other countries. As Amartya Sen (1994) has noted about the absence of famine in democracies, the electoral survival of leaders depends in part on being responsive and attendant to the needs of the voting public; a condition that lowers the probability of total government neglect and may explain why we see lower levels of slavery prevalence across the democracies in the sample. The one exception may be India, which has a longstanding tradition of democracy and high levels of slavery prevalence, although its liberal democracy score is lower than the other democracies in the sample.

Taken together, these findings mark out a new direction in the cross-national analysis of modern slavery. The fight against slavery is now embedded in the United Nations SDGs, and the results here suggest that the pursuit of other SDGs alongside 8.7 (particularly SDG 16 on peace, justice and strong institutions) will complement and enhance the world's ability to address the problem of modern slavery. We show that there may not be a trade-off between globalization and modern slavery. Rather, we show that slavery prevalence is much lower in those countries that are more globalised and wealthier, and those that have higher levels of democ- 
racy. Globalization is not a monolithic global process that necessarily creates conditions for modern slavery. These findings suggest that the pursuit of sustainable development and the establishment of inclusive and democratic institutions can help in the struggle to end modern slavery.

\section{Acknowledgments}

The authors are grateful for the comments, feedback, and support from James Cockayne, Doreen Boyd, Zoe Trodd, Alejandro Quiroz Flores, Facundo Albornoz Crespo, and the Rights Lab at the University of Nottingham.

\section{Conflict of Interests}

The authors declare no conflict of interests.

\section{References}

Abouharb, R., \& Cingranelli, D. (2007). Human rights and structural adjustment. Cambridge: Cambridge University Press.

Bales, K. (1999). Disposable People: New Slavery in the Global Economy. Berkeley: University of California Press.

Bales, K. (2005). Understanding global slavery: A reader. Berkeley, CA: University of California Press.

Bales, K. (2007). Ending slavery: How we free today's slaves. Berkeley, CA: University of California Press.

Bales, K., Hesketh, O., \& Silverman, B. (2015). Modern slavery in the UK: How many victims? Significance, 12(3), 16-21.

Bales, K., Murphy, L., \& Silverman, B. (in press). How many trafficked people are there in Greater New Orleans? Lessons in measurement. Journal of Human Trafficking.

Bales, K., \& Soodalter, R. (2009). The slave next door: Human trafficking and slavery in America today. Berkeley, CA: University of California Press.

Bales, K., Trodd, Z., \& Williamson, A. K. (2009). Modern slavery. Oxford: Oneworld.

Choi-Fitzpatrick, A. (2017). What slaveholders think: How contemporary perpetrators rationalize what they do. New York, NY: Columbia University Press.

Cingranelli, D., Richards, D., \& Clay, C. (2014). CIRI Human Rights Data Project: The Cingranelli-Richards (CIRI) Human Rights Data Project coding manual. Binghamton, NY: State University of New York.

Cockayne, J., Grono, N., \& Panaccione, K. (2016). Slavery and the limits of international criminal justice. Journal of International Criminal Justice, 14(2), 253-267.

Cooper, C., Hesketh, O., Ellis, N., \& Fair, A. (2017). A typology of modern slavery offences in the UK. London: Home Office.

Coppedge, M., Lindberg, S., \& Skaaning, S. E. (2015). Measuring high level democratic principles using the V-Dem data. International Political Science Review,
37(5), 580-593. vDeutsch, F., \& Welzel, C. (2016). The diffusion of values among democracies and autocracies. Global Policy, 7(4), 563-570.

Diamond, L., \& Plattner, M. (2015). Democracy in decline? Baltimore, MD: Johns Hopkins University Press.

Diamond, L., Plattner, M., \& Walker, C. (2016). Authoritarianism on the defensive. Baltimore, MD: Johns Hopkins University Press.

Doorenspleet, R. (2005). Democratic transitions: Exploring the structural sources of the Fourth Wave. Boulder, CO: Lynne Rienner.

Edwards, H., Landman, T., Kernohan, D., \& Nessa, A. (2018). Good neighbours matter: Economic geography and the diffusion of human rights. Spatial Economic Analysis, 13(3), 1-19.

Fariss, C. (2014). Respect for human rights has improved over time: Modelling the changing standard of accountability. American Political Science Review, 108(2), 297-318.

Foweraker, J., \& Treviso, D. (2016). Democracy and its discontents in Latin America. Boulder, CO: Lynne Reiner.

Freedom Fund. (2016). Modern slavery and trafficking in conflict: The UN's response. London and New York, NY: Freedom Fund.

Gygli, S., Haelg, F., Potrafke, N., \& Sturm, J-E. (2019). The KOF Globalisation Index-Revisited. Review of International Organizations, 14(3), 543-574. https://doi. org/10.1007/s11558-019-09344-2

Held, D., \& McGrew, A. (2007). Globalization/antiglobalization: Beyond the great divide. Cambridge: Polity Press.

Held, D., McGrew, A., Goldblatt, D., \& Perraton, J. (1999). Global transformations: Politics, economics, and culture. Cambridge: Polity Press.

Hermann, P. (2010). Globalization revisited. Society and Economy, 32(2), 255-275.

Huntington, S. P. (1991). The Third Wave: Democratization in the late twentieth century. Norman, OK: University of Oklahoma Press.

Inglehart, R. (1997). Modernization and postmodernization. Princeton, NJ: Princeton University Press.

Inglehart, R., \& Welzel, C. (2005). Modernization, cultural change, and democracy: The human development sequence. Cambridge: Cambridge University Press.

International Labour Organization, \& Walk Free Foundation. (2017). Methodology of the global estimates of modern slavery: Forced labour and forced marriage. Geneva: International Labour Organization.

International Organization for Migration. (2018). IOM handbook: Protection and assistance for migrants vulnerable to violence, exploitation and abuse. Geneva: International Organization for Migration.

Janz, N. (2018). Foreign direct investment and repression: An analysis across industry sectors. Journal of Human Rights, 17(2), 163-183.

Jian, B., \& LaFree, G. (2017). Social control, trade openness and human trafficking. Journal of Quantitative 
Criminology, 33, 887-913.

Landman, T. (2005a). Review Article: the Political Science of Human Rights. British Journal of Political Science, 35(3), 549-572.

Landman, T. (2005b). Protecting human rights: A global comparative study. Washington, DC: Georgetown University Press.

Landman, T. (2013). Human rights and democracy: The precarious triumph of ideals. London: Bloomsbury.

Landman, T. (2018). Out of the shadows: Transdisciplinary research on modern slavery. Peace Human Rights Governance, 2(2), 1-15.

Landman, T., \& Carvalho, E. (2009). Measuring human rights. London: Routledge.

Landman, T., \& Carvalho, E. (2016). Issues and methods in comparative politics: An introduction. London and Oxford: Routledge.

Landman, T., \& Larizza, M. (2009). Inequality and human rights: Who controls what, when, and how. International Studies Quarterly, 53(3), 715-736.

League of Nations. (1926). Convention to suppress the slave trade and slavery (25 September 1926, 60 LNTS 253, Registered No. 1414). Retrieved from https:// www.refworld.org/docid/3ae6b36fb.html

LeBaron, G. (2016). Slavery, human trafficking, and forced labour: Implications for international development. In J. Grugel \& D. Hamnett (Eds.), The Palgrave handbook of international development (pp. 381-398). London: Palgrave Macmillan.

LeBaron, G., \& Ayers, A. J. (2013). The rise of "new slavery"? Understanding African unfree labour through neoliberalism. Third World Quarterly, 34(5), 873-892.

Li, Q., \& Reuveny, R. (2003). Economic globalization and democracy: An empirical analysis. British Journal of Political Science, 33, 29-54.

Manzo, K. (2005a). Exploiting West Africa's children: Trafficking, slavery, and uneven development. Area, 37(4), 393-401.

Manzo, K. (2005b). Modern slavery, global capitalism and deproletarianisation in West Africa. Review of African Political Economy, 32(106), 521-534.

Mitchell, N. J., \& McCormick, J. M. (1988). Economic and political explanations of human rights violations. World Politics, 40, 476-498.

Neumayer, E., \& de Soysa, I. (2007). Globalisation, women's rights and forced labour. The World Economy, 30(10), 1510-1535.

Norris, P., \& Inglehart, R. (2019). Cultural backlash: Trump, Brexit and authoritarian populism. Cambridge: Cambridge University Press.

O'Connell Davidson, J. (2014). The making of modern slavery: Whose interests are served by the new abolitionism? London: British Academy Review.

Office of the High Commissioner for Human Rights. (2002). Abolishing slavery and its contemporary forms (HR/PUB/02/4). Geneva: Office of the High Commissioner for Human Rights.
Poe, S. C., \& Tate, C.N. (1994). Repression of human rights to personal integrity in the 1980s: A global analysis. American Political Science Review, 88(4), 853-872.

Poe, S. C., Tate, C.N., \& Keith, L. C. (1999). Repression of the human right to personal integrity revisited: A global cross-national study covering the years 1976-1993. International Studies Quarterly, 43, 291-313.

Potrafke, N. (2015). The evidence on globalization. The World Economy, 38(3), 509-552.

Risse, T., Ropp, S. C., \& Sikkink, K. (Eds.). (1999). The power of human rights: International norms and domestic change. Cambridge: Cambridge University Press.

Risse, T., Ropp, S. C., \& Sikkink, K. (Eds.). (2013). The persistent power of human rights: From commitment to compliance. Cambridge: Cambridge University Press.

Russett, B., \& O'Neal, J. (2001). Triangulating peace: Democracy, interdependence and international organizations. New York, NY: W. W. Norton.

Sen, A. (1994). Development as freedom. Oxford: Oxford University Press.

Sikkink, K. (2011). The justice cascade: How human rights prosecutions are changing world politics. New York, NY: Norton.

Silverman, B. W. (2018). Demonstrating risks is not the same as estimating prevalence. Paper presented at Delta 8.7 Modelling the Risk of Modern Slavery Symposium, United Nations University-Centre for Policy Research, New York, NY, United States. Retrieved from delta87.org/2018/12/demonstrating-risk-notsame-estimating-prevalence

Silverman, B. W. (in press). Multiple systems analysis for the quantification of modern slavery: Classical and Bayesian approaches (with discussion). Journal of the Royal Statistical Society, Series A.

Simmons, B. (2009). Mobilizing human rights: International law in domestic politics. Cambridge: Cambridge University Press.

Smith-Cannoy, H. (2012). Insincere commitments: Human rights treaties, abusive states and citizen activism. Washington, DC: Georgetown University Press.

Squalli, J., \& Wilson, K. (2011). A new measure of trade openness. The World Economy, 34(10), 1745-1770.

Stiglitz, J. (2005). Globalization and its discontents. New York, NY: Penguin.

Stiglitz, J. (2017). Globalization and its discontents revisited: Anti-globalization in the era of Trump. New York, NY: Penguin.

United Nations Development Programme. (2015). Sustainable Development Goals. United Nations Development Programme. Retrieved from https:// www.undp.org/content/undp/en/home/sustainabledevelopment-goals.html

Van Dijk, J., van der Heijden, P. G. M., \& KragtenHeerdink, S. (2016). Multiple systems estimation for estimating the number of victims of human traf- 
ficking across the world. Southahmpton: University of Southampton Institutional Repository. Retrieved from https://eprints.soton.ac.uk/399731

Walk Free Foundation. (2016). The Global Slavery Index 2016. The Global Slavery Index. Retrieved from http://www.globalslaveryindex.org

Walk Free Foundation, \& International Labour Organization. (2018). The Global Slavery Index 2018. The Global Slavery Index. Retrieved from http://www. globalslaveryindex.org

Welzel, C. (2013). Freedom rising: Human power and the quest for emancipation. Cambridge: Cambridge University Press.

Whitehead, L. (1996). The international dimensions of democratization: Europe and the Americas. Oxford: Oxford University Press.

World Economic Forum. (2018). Globalization 4.0: The human experience. Cologny: World Economic Forum. Retrieved from https://www.weforum.org/ agenda/2018/11/globalization-4-what-does-itmean-how-it-will-benefit-everyone

\section{About the Authors}
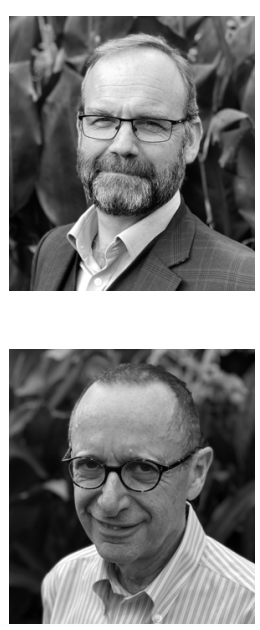

Todd Landman (FRSA) is Professor of Political Science in the School of Politics and International Relations, Pro Vice Chancellor of the Faculty of Social Sciences, and Executive Director of the Rights Lab at the University of Nottingham. He is author of numerous research monographs, articles, and reports on the systematic analysis of development, democracy, and human rights. He has carried out a large number of international consultancy projects for governmental and non-governmental organisations.

Bernard W. Silverman (Sir, FRS) is Professor of Modern Slavery Statistics in the School of Politics and International Relations and Chair of the Modern Slavery Evidence Unit in the Rights Lab at the University of Nottingham. He was the Chief Scientific Advisor to the Home Office (2010-2017). He is a member of the UK Independent Anti-Slavery Commissioner's Advisory Panel and the Prime Minister's Task Force on Modern Slavery. He also serves as an advisor to the Global Fund to End Modern Slavery and the United Nations University Modern Slavery Knowledge Platform. 


\begin{tabular}{|c|c|c|c|c|c|c|c|c|c|c|c|c|c|c|c|c|c|c|c|c|c|c|c|}
\hline & Country & YEAR & REGION & ASIADUM & SSADUM & READUM & KOFTOTAL & CIRIWRP & EPSRAW & EPS2016R & EPS2018R & TRADE & FDI & FDI0716 & VDEM2016 & PTSAI & PTSSD & PCGDP & ARMEDCON1 & LNEPS & LNTRADE & LNFDI & LNPCGDP \\
\hline 1 & Afghanistan & 2018 & ASIA & 1 & 0 & 0 & 38.57 & 1 & 2.22 & NA & 2.22 & 55.92 & 0.48 & 0.0057 & 0.24 & 5 & 5 & 570 & 1 & 0.797507 & 4.023922 & -5.16729 & 6.345636 \\
\hline 2 & Argentina & 2018 & AMERICAS & 0 & 0 & 0 & 63.02 & 1 & 0.13 & NA & 0.13 & 26.12 & 0.59 & 0.0186 & 0.61 & 2 & 2 & 11970 & 0 & -2.04022 & 3.262701 & -3.98459 & 9.390159 \\
\hline 3 & Armenia & 2018 & $\begin{array}{l}\text { RUSSIA AND } \\
\text { EURASIA }\end{array}$ & 0 & 0 & 1 & 67.09 & 1 & 0.34 & NA & 0.34 & 75.92 & 3.21 & 0.0515 & 0.23 & 3 & 3 & 3770 & 0 & -1.07881 & 4.32968 & -2.96617 & 8.23483 \\
\hline 4 & Bangladesh & 2016 & ASIA & 1 & 0 & 0 & 45.54 & 0 & 0.95 & 0.95 & NA & 37.95 & 1.05 & 0.0124 & 0.16 & 4 & 4 & 1330 & 1 & -0.05129 & 3.63627 & -4.39006 & 7.192934 \\
\hline 5 & Bolivia & 2016 & AMERICAS & 0 & 0 & 0 & 57.74 & 1 & 0.44 & 0.44 & NA & 56.4 & 1.54 & 0.0287 & 0.4 & 1 & 3 & 3070 & 0 & -0.82098 & 4.032469 & -3.55086 & 8.029433 \\
\hline 6 & Botswana & 2016 & $\begin{array}{l}\text { SUBSAHARAN } \\
\text { AFRICA }\end{array}$ & 0 & 1 & 0 & 56.22 & 0 & 0.52 & NA & -0.16 & 97.13 & 0.83 & 0.0374 & 0.58 & 2 & 2 & 6750 & 0 & -0.65393 & 4.57605 & -3.28608 & 8.817298 \\
\hline 7 & Botswana & 2018 & $\begin{array}{l}\text { SUBSAHARAN } \\
\text { AFRICA }\end{array}$ & 0 & 1 & 0 & 56.52 & 0 & 0.36 & 0.36 & -0.16 & 97.13 & 0.83 & 0.0374 & 0.58 & 2 & 2 & 6750 & 0 & -1.02165 & 4.57605 & -3.28608 & 8.817298 \\
\hline 8 & Brazil & 2016 & AMERICAS & 0 & 0 & 0 & 59.64 & 1 & 0.08 & 0.08 & NA & 24.57 & 4.34 & 0.0351 & 0.57 & 4 & 3 & 8840 & 0 & -2.52573 & 3.201526 & -3.34955 & 9.087042 \\
\hline 9 & Cambodia & 2016 & ASIA & 1 & 0 & 0 & 57.89 & 0 & 1.65 & 1.65 & 1.68 & 126.95 & 11.43 & 0.1148 & 0.11 & 3 & 2 & 1140 & 0 & 0.500775 & 4.843793 & -2.16456 & 7.038784 \\
\hline 10 & Cambodia & 2018 & ASIA & 1 & 0 & 0 & 56.67 & 0 & 1.68 & 1.65 & 1.68 & 126.95 & 11.43 & 0.1148 & 0.11 & 3 & 2 & 1140 & 0 & 0.518794 & 4.843793 & -2.16456 & 7.038784 \\
\hline 11 & Cameroon & 2018 & $\begin{array}{l}\text { SUBSAHARAN } \\
\text { AFRICA }\end{array}$ & 0 & 1 & 0 & 48.08 & 0 & 0.69 & NA & 0.69 & 42 & 2.06 & 0.0182 & 0.17 & 4 & 3 & 1400 & 1 & -0.37106 & 3.73767 & -4.00633 & 7.244227 \\
\hline 12 & Chile & 2016 & AMERICAS & 0 & 0 & 0 & 77.13 & 1 & 0.15 & 0.15 & 0.08 & 55.51 & 4.95 & 0.0846 & 0.76 & 2 & 2 & 13540 & 0 & -1.89712 & 4.016563 & -2.46982 & 9.513404 \\
\hline 13 & Chile & 2018 & AMERICAS & 0 & 0 & 0 & 74.14 & 1 & 0.08 & 0.15 & 0.08 & 55.51 & 4.95 & 0.0846 & 0.76 & 2 & 2 & 13540 & 0 & -2.52573 & 4.016563 & -2.46982 & 9.513404 \\
\hline 14 & Colombia & 2018 & AMERICAS & 0 & 0 & 0 & 61.68 & 1 & 0.27 & NA & 0.27 & 36.47 & 4.94 & 0.0404 & 0.52 & 3 & 3 & 6310 & 1 & -1.30933 & 3.59649 & -3.20893 & 8.749891 \\
\hline 15 & Czech Republic & 2018 & EUROPE & 0 & 0 & 0 & 83.41 & 1 & 0.13 & NA & 0.13 & 151.6 & 5.56 & 0.0384 & 0.78 & 1 & 1 & 17540 & 0 & -2.04022 & 5.021245 & -3.2597 & 9.77224 \\
\hline 16 & $\begin{array}{l}\text { Democratic } \\
\text { Republic of } \\
\text { the Congo }\end{array}$ & 2018 & $\begin{array}{l}\text { SUBSAHARAN } \\
\text { AFRICA }\end{array}$ & 0 & 1 & 0 & 41.14 & 1 & 1.37 & NA & 1.37 & 59.59 & 2.35 & 0.0574 & 0.12 & 5 & 5 & 430 & 1 & 0.314811 & 4.087488 & -2.85771 & 6.063785 \\
\hline 17 & Egypt & 2018 & $\begin{array}{l}\text { MIDDLE EAST AND } \\
\text { NORTH AFRICA }\end{array}$ & 0 & 0 & 0 & 60.87 & 0 & 0.55 & NA & 0.55 & 30.02 & 2.44 & 0.0244 & 0.17 & 4 & 4 & 3410 & 1 & -0.59784 & 3.401864 & -3.71317 & 8.134467 \\
\hline 18 & Ethiopia & 2016 & $\begin{array}{l}\text { SUBSAHARAN } \\
\text { AFRICA }\end{array}$ & 0 & 1 & 0 & 43.67 & 0 & 0.41 & 0.41 & 0.61 & 35.51 & 5.46 & 0.0272 & 0.12 & 4 & 5 & 660 & 1 & -0.8916 & 3.569814 & -3.60454 & 6.49224 \\
\hline 19 & Ethiopia & 2018 & $\begin{array}{l}\text { SUBSAHARAN } \\
\text { AFRICA }\end{array}$ & 0 & 1 & 0 & 42.51 & 0 & 0.61 & 0.41 & 0.61 & 35.51 & 5.46 & 0.0272 & 0.12 & 4 & 5 & 660 & 1 & -0.4943 & 3.569814 & -3.60454 & 6.49224 \\
\hline 20 & Georgia & 2018 & $\begin{array}{l}\text { RUSSIA AND } \\
\text { EURASIA }\end{array}$ & 0 & 0 & 1 & 72.5 & 0 & 0.23 & NA & 0.23 & 102.93 & 11.04 & 0.0968 & 0.55 & 2 & 2 & 3830 & 0 & -1.46968 & 4.634049 & -2.33511 & 8.25062 \\
\hline 21 & Ghana & 2016 & $\begin{array}{l}\text { SUBSAHARAN } \\
\text { AFRICA }\end{array}$ & 0 & 1 & 0 & 61.03 & 1 & 0.38 & 0.38 & 0.48 & 89.34 & 8.14 & 0.0696 & 0.55 & 2 & 3 & 1380 & 0 & -0.96758 & 4.492449 & -2.66499 & 7.229839 \\
\hline 22 & Ghana & 2018 & $\begin{array}{l}\text { SUBSAHARAN } \\
\text { AFRICA }\end{array}$ & 0 & 1 & 0 & 55.83 & 1 & 0.48 & 0.38 & 0.48 & 89.34 & 8.14 & 0.0696 & 0.55 & 2 & 3 & 1380 & 0 & -0.73397 & 4.492449 & -2.66499 & 7.229839 \\
\hline 23 & Guatemala & 2016 & AMERICAS & 0 & 0 & 0 & 63.09 & 0 & 0.84 & 0.84 & 0.2 & 4 & 1.71 & 0.0211 & 0.4 & 2 & 3 & 3790 & 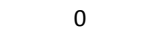 & -0.17435 & 850147 & -3.85848 & 8.240121 \\
\hline 24 & Guatemala & 2018 & AMERI & 0 & 0 & 0 & & 0 & & 0.8 & 0. & 47 & 1.71 & 0.0211 & & 2 & 3 & 3790 & 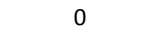 & & & -3.85848 & 8.240121 \\
\hline 25 & Haiti & 2018 & AMERICAS & 0 & 0 & 0 & 47.33 & 0 & 0.55 & NA & 0.55 & 73.34 & 1.32 & 0.0145 & 0.31 & 2 & 3 & 780 & 0 & -0.59784 & 4.295106 & -4.23361 & 6.659294 \\
\hline 26 & Honduras & 2018 & AMERICAS & 0 & 0 & 0 & 61.71 & 0 & 0.33 & $\mathrm{~N}$ & 0.33 & 100.49 & 5.3 & 0.0612 & 0.33 & 3 & 3 & 2150 & 0 & -1.10866 & 4.610058 & -2.79361 & 7.673223 \\
\hline 27 & Hungary & 2016 & EUROPE & 0 & 0 & 0 & & 1 & 0.23 & 0.2 & 0 & 168.99 & 55.49 & 0.1594 & 0.57 & 2 & 2 & 12570 & 0 & -1.46968 & 5.129839 & -1.83634 & 9.439068 \\
\hline 28 & Hungary & 2018 & EUROPE & 0 & 0 & 0 & 84.2 & 1 & 0.26 & 0.23 & 0.26 & 168.99 & 55.49 & 0.1594 & 0.57 & 2 & 2 & 12570 & 0 & -1.34707 & 5.129839 & -1.83634 & 9.439068 \\
\hline 29 & India & 2016 & ASIA & 1 & 0 & 0 & 61.18 & 1 & 1. & 14 & 0.61 & 40.35 & 1.95 & 0.0199 & 0. & 4 & 4 & 1670 & 1 & 0.336472 & 3.697591 & -3.91704 & 7.420579 \\
\hline 30 & India & 2018 & ASIA & 1 & 0 & 0 & 56.77 & 1 & 0.61 & 1.4 & 0. & 40.35 & 1.95 & 0.0199 & 0. & 4 & 4 & 1670 & 1 & -0.4943 & 3.697591 & -3.91704 & 7.420579 \\
\hline 31 & Indonesia & 2016 & ASIA & 1 & 0 & 0 & 62.97 & 0 & 0.29 & 0.29 & 0.47 & 37.44 & 0.49 & 0.0197 & 0.4 & 3 & 3 & 3400 & 0 & -1.23787 & 3.62274 & -3.92714 & 8.131531 \\
\hline 32 & Indonesi & 2018 & ASIA & 1 & 0 & 0 & & 0 & 0. & 0.29 & & 37.44 & 0.49 & 0.0197 & & 3 & J & 3400 & 0 & & 274 & & 8.131531 \\
\hline 33 & Jordan & 2018 & $\begin{array}{l}\text { MIDDLE EAST AND } \\
\text { NORTH AFRICA }\end{array}$ & 0 & 0 & 0 & 74.31 & 0 & 0.19 & NA & 0.19 & 91.32 & 4.02 & 0.0674 & 0.23 & 3 & 3 & 3920 & 1 & -1.66073 & 4.51437 & -2.69711 & 8.273847 \\
\hline 34 & Lat & 2018 & EUROPE & 0 & 0 & 0 & & 1 & & $\mathrm{~N}$ & & 119.19 & 0.88 & & & 1 & 1 & 14570 & 0 & & & & 9.58672 \\
\hline 35 & Lebanon & 2018 & $\begin{array}{l}\text { MIDDLE EAST AND } \\
\text { NORTH AFRICA }\end{array}$ & 0 & 0 & 0 & 65.11 & 0 & 0.17 & NA & 0.17 & 72.61 & 5.18 & 0.0815 & 0.32 & 2 & 3 & 7980 & 0 & -1.77196 & 4.285103 & -2.50715 & 8.984694 \\
\hline
\end{tabular}




\begin{tabular}{|c|c|c|c|c|c|c|c|c|c|c|c|c|c|c|c|c|c|c|c|c|c|c|c|}
\hline & Country & YEAR & REGION & ASIADUM & SSADUM & READUM & KOFTOTAL & CIRIWRP & EPSRAW & EPS2016R & EPS2018R & TRADE & FDI & FDI0716 & VDEM2016 & PTSAI & PTSSD & PCGDP & ARMEDCON1 & LNEPS & LNTRADE & LNFDI & LNPCGDP \\
\hline 36 & Malawi & 2018 & $\begin{array}{l}\text { SUBSAHARAN } \\
\text { AFRICA }\end{array}$ & 0 & 1 & 0 & 46.24 & 1 & 0.75 & NA & 0.75 & 77.91 & 5.99 & 0.0526 & 0.4 & 2 & 3 & 320 & 0 & -0.28768 & 4.355554 & -2.94504 & 5.768321 \\
\hline 37 & Mauritania & 2016 & $\begin{array}{l}\text { SUBSAHARAN } \\
\text { AFRICA }\end{array}$ & 0 & 1 & 0 & 50.6 & 1 & 1.06 & 1.06 & 2.15 & 100.53 & 5.72 & 0.1074 & 0.16 & 3 & 3 & 1130 & 0 & 0.058269 & 4.610456 & -2.2312 & 7.029973 \\
\hline 38 & Mauritania & 2018 & $\begin{array}{l}\text { SUBSAHARAN } \\
\text { AFRICA }\end{array}$ & 0 & 1 & 0 & 51.1 & 1 & 2.15 & 1.06 & 2.15 & 100.53 & 5.72 & 0.1074 & 0.16 & 3 & 3 & 1130 & 0 & 0.765468 & 4.610456 & -2.2312 & 7.029973 \\
\hline 39 & Mexico & 2016 & AMERICAS & 0 & 0 & 0 & 71.49 & 1 & 0.3 & 0.3 & 0.27 & 76.22 & 3.29 & 0.0263 & 0.48 & 4 & 2 & 9040 & 0 & -1.20397 & 4.333624 & -3.63819 & 9.109414 \\
\hline 40 & Mexico & 2018 & AMERICAS & 0 & 0 & 0 & 70.46 & 1 & 0.27 & 0.3 & 0.27 & 76.22 & 3.29 & 0.0263 & 0.48 & 4 & 2 & 9040 & 0 & -1.30933 & 4.333624 & -3.63819 & 9.109414 \\
\hline 41 & Mongolia & 2018 & ASIA & 1 & 0 & 0 & 64.09 & 1 & 1.24 & NA & 1.24 & 95.64 & -37.17 & 0.1161 & 0.51 & 3 & 2 & 3590 & 0 & 0.215111 & 4.560591 & -2.1533 & 8.185907 \\
\hline 42 & Morocco & 2018 & $\begin{array}{l}\text { MIDDLE EAST AND } \\
\text { NORTH AFRICA }\end{array}$ & 0 & 0 & 0 & 67.01 & 1 & 0.24 & NA & 0.24 & 80.42 & 2.24 & 0.0269 & 0.25 & 3 & 2 & 2850 & 0 & -1.42712 & 4.387263 & -3.61563 & 7.955074 \\
\hline 43 & Myanmar & 2016 & ASIA & 1 & 0 & 0 & 43.57 & 1 & 0.96 & 0.96 & 1.1 & 39.06 & 5.18 & 0.0378 & 0.27 & 5 & 5 & 1190 & 1 & -0.04082 & 3.665099 & -3.27545 & 7.081708 \\
\hline 44 & Myanmar & 2018 & ASIA & 1 & 0 & 0 & 39.8 & 1 & 1 & 0.96 & 1.1 & 39.06 & 5.18 & 0.0378 & 0.27 & 5 & 5 & 1190 & 1 & 0.09531 & 3.665099 & -3.27545 & 7.081708 \\
\hline 45 & Nepal & 2016 & ASIA & 1 & 0 & 0 & 47.55 & 1 & 0.82 & 0.82 & 0.6 & 48.88 & 0.5 & 0.0034 & 0.45 & 3 & 3 & 730 & 0 & -0.19845 & 3.889368 & -5.68398 & 6.593045 \\
\hline 46 & Nepal & 2018 & ASIA & 1 & 0 & 0 & 45.59 & 1 & 0.6 & 0.82 & 0.6 & 48.88 & 0.5 & 0.0034 & 0.45 & 3 & 3 & 730 & 0 & -0.51083 & 3.889368 & -5.68398 & 6.593045 \\
\hline 47 & Nigeria & 2016 & $\begin{array}{l}\text { SUBSAHARAN } \\
\text { AFRICA }\end{array}$ & 0 & 1 & 0 & 54.39 & 0 & 0.48 & 0.48 & 0.76 & 20.72 & 1.1 & 0.0152 & 0.47 & 5 & 4 & 2450 & 1 & -0.73397 & 3.031099 & -4.18646 & 7.803843 \\
\hline 48 & Nigeria & 2018 & $\begin{array}{l}\text { SUBSAHARAN } \\
\text { AFRICA }\end{array}$ & 0 & 1 & 0 & 54.93 & 0 & 0.76 & 0.48 & 0.76 & 20.72 & 1.1 & 0.0152 & 0.47 & 5 & 4 & 2450 & 1 & -0.27444 & 3.031099 & -4.18646 & 7.803843 \\
\hline 49 & Pakistan & 2016 & ASIA & 1 & 0 & 0 & 53.53 & 0 & 1.13 & 1.13 & 1.68 & 25.31 & 0.89 & 0.0117 & 0.27 & 4 & 4 & 1500 & 1 & 0.122218 & 3.2 & -4.44817 & 7.313221 \\
\hline 50 & Pakistan & 2018 & ASIA & 1 & 0 & 0 & 51.7 & 0 & 1.68 & 1.13 & 1.68 & 25.31 & 0.89 & 0.0117 & 0.27 & 4 & 4 & 1500 & 1 & 0.518794 & 3.2312 & -4.44817 & 7.313221 \\
\hline 51 & Philippines & 2016 & ASIA & 1 & 0 & 0 & 66.97 & 1 & 0.4 & 0.4 & 0.77 & 64.9 & 2.72 & 0.0155 & 0.38 & 5 & 5 & 3580 & 1 & -0.91629 & 4.172848 & -4.16692 & 8.183118 \\
\hline 52 & Philippines & 2018 & ASIA & 1 & 0 & 0 & 64.08 & 1 & & 0.4 & 0.77 & 64.9 & 2.72 & 0.0155 & & 5 & 5 & 3580 & 1 & -0.26136 & & -4.16692 & 8.183118 \\
\hline 53 & Poland & 2016 & EUROPE & 0 & 0 & 0 & 8 & 2 & 0 & 0.48 & 0.21 & 100.47 & 3.55 & 0.0308 & 0.5 & 2 & 1 & 12690 & 0 & -0.73397 & 4.609859 & -3.48024 & 9.448569 \\
\hline 54 & Poland & 2018 & EUROPE & 0 & 0 & 0 & 78.72 & 2 & 0.21 & 0.48 & 0.21 & 100.47 & 3.55 & 0.0308 & 0.5 & 2 & 1 & 12690 & 0 & -1.56065 & 4.609859 & -3.48024 & 9.448569 \\
\hline 55 & Romania & 2018 & EUROPE & 0 & 0 & 0 & 77.88 & 1 & 0.35 & NA & 0.35 & 83.57 & 3.33 & 0.0301 & 0.65 & 2 & 2 & 9480 & 0 & -1.04982 & 4.425684 & -3.50323 & 9.15694 \\
\hline 56 & Russia & 2016 & $\begin{array}{l}\text { RUSSIA AND } \\
\text { EURASIA }\end{array}$ & 0 & 0 & 1 & 72.29 & 0 & 0.73 & 0.73 & 0.53 & 46.23 & 2.53 & 0.0263 & 0.12 & 4 & 4 & 9720 & 1 & -0.31471 & 3.833629 & -3.63819 & 9.181941 \\
\hline 57 & Russia & 2018 & $\begin{array}{l}\text { RUSSIA AND } \\
\text { EURASIA }\end{array}$ & 0 & 0 & 1 & 69.06 & 0 & 0.53 & 0.73 & 0.53 & 46.23 & 2.53 & 0.0263 & 0.12 & 4 & 4 & 9720 & 1 & -0.63488 & 3.833629 & -3.63819 & 9.181941 \\
\hline 58 & Serbia & 2018 & EUROPE & 0 & 0 & 0 & 75. & 1 & 0.16 & NA & 0.16 & 107.5 & 6.15 & 0.0662 & 0. & 1 & 2 & 5310 & 0 & -1.83258 & 4.677491 & -2.71507 & 8.577347 \\
\hline 59 & Singapore & 2018 & ASIA & 1 & 0 & 0 & 80.01 & 1 & 0.34 & NA & 0.34 & 310.26 & 23.97 & 0.2014 & 0.34 & 2 & 1 & 51880 & 0 & -1.07881 & 5.737411 & -1.60246 & 10.85669 \\
\hline 60 & South Africa & 2016 & $\begin{array}{l}\text { SUBSAHARAN } \\
\text { AFRICA }\end{array}$ & 0 & 1 & 0 & 69.89 & 1 & 0.45 & 0.45 & 0.28 & 60.79 & 0.75 & 0.016 & 0.61 & 3 & 4 & 5490 & 0 & -0.79851 & 4.107425 & -4.13517 & 8.610683 \\
\hline 61 & South Africa & 2018 & $\begin{array}{l}\text { SUBSAHARAN } \\
\text { AFRICA }\end{array}$ & 0 & 1 & 0 & 68.63 & 1 & 0.28 & 0.45 & 0.28 & 60.79 & 0.75 & 0.016 & 0.61 & 3 & 4 & 5490 & 0 & -1.27297 & 4.107425 & -4.13517 & 8.610683 \\
\hline 62 & Sri Lanka & 2016 & ASIA & 1 & 0 & 0 & 58.92 & 1 & & 0 & & 50.01 & 1.1 & 0.0121 & 0. & 3 & 3 & 3780 & 0 & -1.51413 & 3.912223 & -4.41455 & 8.237479 \\
\hline 63 & Sri Lanka & 2018 & ASIA & 1 & 0 & 0 & & 1 & & 0. & & 50.01 & 1.1 & 0.0121 & 0.5 & 3 & 3 & 3780 & 0 & -1 & 3.9 & -4.41455 & 8.237479 \\
\hline 64 & Thailand & 2018 & ASIA & 1 & 0 & 0 & 68.15 & 0 & 0.89 & NA & 0.89 & 121.66 & 0.74 & 0.0241 & 0.11 & 3 & 3 & 5640 & 1 & -0.11653 & 4.80123 & -3.72554 & 8.637639 \\
\hline 65 & Tunisia & 2016 & $\begin{array}{l}\text { MIDDLE EAST AND } \\
\text { NORTH AFRICA }\end{array}$ & 0 & 0 & 0 & 67.3 & 1 & 0.77 & 0.77 & 0.22 & 91.44 & 1.48 & 0.0286 & 0.66 & 3 & 3 & 3690 & 0 & -0.26136 & 4.515683 & -3.55435 & 8.213382 \\
\hline 66 & Tunisia & 2018 & $\begin{array}{l}\text { MIDDLE EAST AND } \\
\text { NORTH AFRICA }\end{array}$ & 0 & 0 & 0 & 64.86 & 1 & 0.22 & 0.77 & 0.22 & 91.44 & 1.48 & 0.0286 & 0.66 & 3 & 3 & 3690 & 0 & -1.51413 & 4.515683 & -3.55435 & 8.213382 \\
\hline 67 & Uganda & 2018 & $\begin{array}{l}\text { SUBSAHARAN } \\
\text { AFRICA }\end{array}$ & 0 & 1 & 0 & 52.66 & 0 & 0.76 & NA & 0.76 & 47.22 & 2.6 & 0.0404 & 0.28 & 3 & 3 & 630 & 1 & -0.27444 & 3.854818 & -3.20893 & 6.44572 \\
\hline 68 & Ukraine & 2018 & $\begin{array}{l}\text { RUSSIA AND } \\
\text { EURASIA }\end{array}$ & 0 & 0 & 1 & 70.6 & 0 & 0.67 & NA & 0.67 & 104.81 & 3.69 & 0.0419 & 0.22 & 4 & 4 & 2310 & 1 & -0.40048 & 4.652149 & -3.17247 & 7.745003 \\
\hline 69 & Vietnam & 2016 & ASIA & 1 & 0 & 0 & 27 & 0 & 0 & 0.15 & 0.45 & 184.69 & 6.14 & 0.0624 & 0. & 3 & 3 & 2100 & 0 & -1.89712 & 5.218679 & -2.77419 & 7.649693 \\
\hline 70 & Vietnam & 2018 & ASIA & 1 & 0 & 0 & 59.7 & 0 & 0.45 & 0.15 & 0.45 & 184.69 & 6.14 & 0.0624 & 0.2 & 3 & 3 & 2100 & 0 & -0.79851 & 5.218679 & -2.77419 & 7.649693 \\
\hline
\end{tabular}

